PRINT ISSN 1119-8362
Full-text Available Online at

https://www.ajol.info/index.php/jasem

http://ww.bioline.org.br/ja
J. Appl. Sci. Environ. Manage.

Vol. 25 (5) 689-693 May 2021

\title{
Rapid Assessment of the Water Chemistry of Public Water Supply in Abeokuta, South- West Nigeria
}

\author{
${ }^{* 1}$ ODJEGBA, EE; ${ }^{1}$ BANKOLE, AO; ${ }^{1}$ SADIQ, AY; ${ }^{2}$ BUSARI, IO; ${ }^{1}$ LAYI-ADIGUN, BO \\ ${ }^{*}$ Department of Water Resources Management and Agrometeorology, Federal University of Agriculture, Abeokuta, Ogun State, Nigeria
${ }^{2}$ Department of Biological, Geological and Environmental Sciences, University of Bologna, Italy \\ *Corresponding Author Email: odjegbaee@funaab.edu.ng
}

\begin{abstract}
The study examined the water supply situation in Abeokuta, with emphasis on the quality of water distributed by the Ogun State Water Corporation from the treatment plant of the Abeokuta Water Scheme. Water samples were collected from standpipes (taps) across the city randomly selected using the stratified random sampling method and was analysed for physical and chemical parameters: $\mathrm{pH}$, total dissolved solids (TDS), electrical conductivity (EC), total alkalinity, total hardness, calcium, magnesium, potassium, sodium, nitrate, bicarbonate, sulphate and chloride. The result of the physical and chemical parameters was subjected to statistical analyses using the multivariate t-test. The result of the treated water was further compared with the result of the analyses of raw water obtained from the source of water used in the treatment plant.
\end{abstract}

\section{DOI: $\underline{\text { https://dx.doi.org/10.4314/jasem.v25i5.1 }}$}

Copyright: Copyright (C) 2021 Odjegba et al. This is an open access article distributed under the Creative Commons Attribution License (CCL), which permits unrestricted use, distribution, and reproduction in any medium, provided the original work is properly cited.

Dates: Received: 20 March 2021; Revised: 27 April 2021; Accepted: 07 May 2021

Keywords: Water supply, treatment plant, analyses, water samples, treated water

Increased rural-urban migration, conditioned by the quest for greener pastures has continuously stretched the barely sufficient urban amenities - especially water supply. In low-income countries particularly in Sub-Sharan Africa, residents in urban areas mostly result to self-supply and communal water supply systems as coping strategy (Hadipuro et al., 2013; Sutton and Butterworth, 2021). For instance, a World Health Organization 2019 report indicated that only $57 \%$ of the population in Sub-Sharan Africa had access to improved, fully functional, readily available, easily accessible and safe water supply (WHO, 2019). In the race towards SDG 2030, affordable, accessible and safe water is still a challenge (Ahmad, 2017). In Nigeria, water is still not accessible to a large percentage of the population in adequate quantity and quality. A 2020 joint report of Nigeria's Federal Ministry of Water Resources, National Bureau of Statistics and United Nations Children's Fund (UNICEF) indicates that $68 \%$ of the country's population lacks access to basic water supply service. The provision of water supply for public consumption and use in Nigeria is the constitutional responsibility of the Federal, State and Local Governments (Balogun and Redina, 2019).

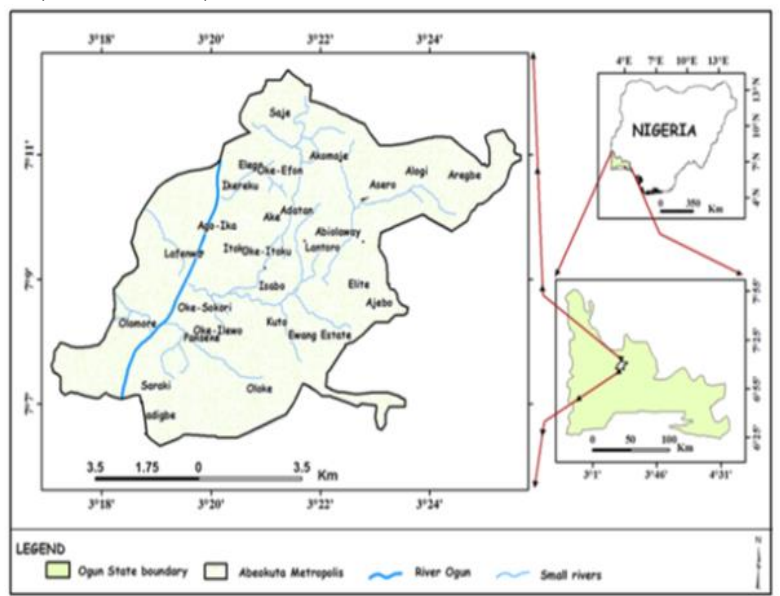

Fig 1: Map of Ogun State, Nigeria showing Abeokuta city. ( Sadiq et al., 2020)

*Corresponding Author Email: odjegbaee@funaab.edu.ng 
All the 36 states including the Federal Capital Territory have Water Boards/Corporations or Public Utilities Boards that manage their public water utilities. Public utilities are functional across Nigeria; however, coverage and reliability are some of the many concerns (Akoteyon, 2019). Studies have also shown that water quality challenges have plagued public water systems (Akpor and Muchie, 2011, Odjegba et al., 2015, Balogun et al., 2017, Akoteyon, 2019). The focus of this study to assess the quality of public water supplied to Abeokuta city by the Ogun State Water Corporation and the effectiveness of the treatment process. Abeokuta is the capital of Ogun State. Public water supply is provided by the Ogun State Water Corporation through the Abeokuta Water Scheme. The source of water for the treatment plant at the Abeokuta Water Scheme is the Ogun River. Abeokuta city (Figure 1), lies between latitude $7^{0} 5^{\prime} \mathrm{N}$ and $7^{0} 20^{\prime} \mathrm{N}$ and longitude $3^{\circ} 17^{\prime} \mathrm{E}-3^{0} 20^{\prime} \mathrm{E}$. It is easily accessible from Lagos, the industrial capital of Nigeria and the nation's major seaport.

The study area has a tropical climate, with distinct wet season (April-October) and dry season (NovemberMarch), and it is controlled by the prevailing southwest monsoon-wind reaching the land from the limit of Gulf of Guinea and the dry continental north - east wind (Harmattan) originating from the Sahara Desert. The wet season has two peak regimes, which are separated by the August break. The mean annual rainfall and temperature are about $1,270 \mathrm{~mm}$ and $28^{\circ} \mathrm{C}$ respectively while the estimated mean annual potential evaporation is $1,100 \mathrm{~mm}$.

\section{MATERIALS AND METHOD}

The Rapid Assessment of Drinking Water Quality (RADWQ) was used (Ince et al., 2004). The sampling approach was used to select 40 sampling locations across Abeokuta city. Water samples were collected from public taps across the city. Water samples were analysed for physical and chemical parameters: $\mathrm{pH}$, total dissolved solids (TDS), electrical conductivity (EC), total alkalinity, total hardness, calcium, magnesium, potassium, sodium, nitrate, bicarbonate, sulphate and chloride. The results of physical and chemical parameters for the tap water were compared with result of the analyses of raw water obtained from the source of water for treatment. This was done to ascertain the effectiveness of the water treatment process. Both results were further compared with the World Health Organisation (WHO), 2017 Guidelines for Drinking Water Quality. Result of the physical and chemical parameters was subjected to multivariate statistical analyses using $\mathrm{t}$ - test.

\section{RESULTS AND DISCUSSION}

The result of the physical and chemical parameters (Table 1) showed a $\mathrm{pH}$ range of $5.63-7.44$ with a mean of $6.91 \pm 0.36$. When compared with World Health Organisation (WHO) and Standards Organisation of Nigeria (SON) standards for drinking water quality $(6.5-8.5)$, the $\mathrm{pH}$ values for 11 samples were found to be below 6.5 , an indication that the water is acidic. Diverse factors are responsible for low $\mathrm{pH}$ in drinking water. Dirisu et al. (2016) reports that carbon-dioxide and sodium carbonate create low $\mathrm{pH}$. Dirisu et al. (2016) stated further that organic matter decomposition leads to the release of carbon dioxide which combines with water to form carbonic acid, a weak acid that leads to low $\mathrm{pH}$. However, $\mathrm{pH}$ as a primary standard parameter has no health implication (WHO, 2017). The EC and TDS values ranged from $106 \mu \mathrm{S} / \mathrm{cm}-202 \mu \mathrm{S} / \mathrm{cm}$ with a mean of $132.10 \pm 18.23$ $\mu \mathrm{S} / \mathrm{cm}$, and between $53 \mathrm{mg} / \mathrm{L}$ and $101 \mathrm{mg} / \mathrm{L}$ with a mean of $66.07 \pm 9.19 \mathrm{mg} / \mathrm{L}$ respectively. The range of values for EC and TDS fell within the SON acceptable limit of $1000 \mu \mathrm{S} / \mathrm{cm}$ and $500 \mathrm{mg} / \mathrm{L}$ respectively. EC is the measure of the capacity water to conduct electricity, while TDS is defined by the presence of inorganic salts and organic matter in water (Rusydi, 2018). EC has no direct human health impact, although, high concentrations could decrease the aesthetic value of water (Rahmanian et al., 2015) Elevated TDS concentration may result in laxative or constipation effects (Meride and Ayenew, 2016).

Total alkalinity and total hardness had values ranging from $6 \mathrm{mg} / \mathrm{L}-30 \mathrm{mg} / \mathrm{L}$ with a mean of $8.34 \pm 3.50$ $\mathrm{mg} / \mathrm{L}$ and $16 \mathrm{mg} / \mathrm{L}-66 \mathrm{mg} / \mathrm{L}$ with a mean of $43.39 \pm$ $7.24 \mathrm{mg} / \mathrm{L}$ respectively and they both fell within the allowable limit of $150 \mathrm{mg} / \mathrm{L}$ set by SON and $100 \mathrm{mg} / \mathrm{L}$ by WHO respectively. Consumption of water with high hardness value can lead to gastrointestinal irritation (Alam et al., 2017). Alkalinity and hardness are collective used in predicting the corrosivity and scale formation of water in distribution networks (Boyd et al., 2016). The results of sodium indicated that it had values ranging from $2 \mathrm{mg} / \mathrm{L}-11 \mathrm{mg} / \mathrm{L}$ with a mean of $4.74 \pm 2.13 \mathrm{mg} / \mathrm{L}$, while that of $\mathrm{Mg}$ was between $6 \mathrm{mg} / \mathrm{L}-40 \mathrm{mg} / \mathrm{L}$ with a mean of $17.30 \pm 6$ $\mathrm{mg} / \mathrm{L}$ respectively. Sodium ion values were below the maximum acceptable limit of $200 \mathrm{mg} / \mathrm{L}$ set by $\mathrm{SON}$, while the values for magnesium were outrageously higher than the $0.2 \mathrm{mg} / \mathrm{L}$ and $0.4 \mathrm{mg} / \mathrm{L}$ set by $\mathrm{SON}$ and WHO respectively. Sodium is used for maintaining osmolarity, homeostasis and physiological functions in humans, though for hypertensive patients sodium concentration of $20 \mathrm{mg} / \mathrm{L}$ in water is recommended (Freije et al., 2019). Although it values were very high, magnesium is an essential element needed in good quantity by the human body (Chellan and Sadler, 
2015). The recommended dietary amount of magnesium is $6 \mathrm{mg} / \mathrm{kg}$ per day (Gröber et al., 2015). Therefore, for individuals with borderline magnesium deficiency, waterborne magnesium could make an important contribution to their total intake. A lack of magnesium leads to a decrease in the concentration of intracellular potassium and an increase in calcium levels (Cunha et al., 2012).

Table 1: Physical and chemical composition of the water samples

\begin{tabular}{llllll}
\hline Parameters & \multicolumn{3}{c}{ Treated water } & \multicolumn{2}{c}{ Standards } \\
\cline { 2 - 6 } & Range & Mean & $\begin{array}{l}\text { Standard } \\
\text { Deviation }\end{array}$ & $\begin{array}{l}\text { (WHO, } \\
\text { 2017) }\end{array}$ & SON (2007) \\
\hline pH & $5.63-7.44$ & 6.91 & 0.36 & $6.5-8.5$ & $6.5-8.5$ \\
EC & $106-202$ & 132.10 & 18.23 & - & $1000 \mathrm{mg} / \mathrm{L}$ \\
TDS & $53-101$ & 66.07 & 9.19 & - & $500 \mathrm{mg} / \mathrm{L}$ \\
Total alkalinity & $6-30$ & 8.34 & 3.50 & $100 \mathrm{mg} / \mathrm{L}$ & - \\
Total hardness & $16-66$ & 43.39 & 7.24 & - & $150 \mathrm{mg} / \mathrm{L}$ \\
Cal & $10-36$ & 26.37 & 4.80 & $50 \mathrm{mg} / \mathrm{L}$ & - \\
Na & $6-40$ & 4.74 & 6 & - & $200 \mathrm{mg} / \mathrm{L}$ \\
Mg & $2-11$ & 17.3 & 2.13 & $0.4 \mathrm{mg} / \mathrm{L}$ & $0.2 \mathrm{mg} / \mathrm{L}$ \\
$\mathbf{K}$ & $0-6$ & 1.38 & 0.83 & - & - \\
$\mathbf{C l}$ & $7-43$ & 16.53 & 0.55 & $250 \mathrm{mg} / \mathrm{L}$ & $250 \mathrm{mg} / \mathrm{L}$ \\
$\mathbf{N O}$ & $0.01-4.23$ & 0.23 & 5.90 & $50 \mathrm{mg} / \mathrm{L}$ & $50 \mathrm{mg} / \mathrm{L}$ \\
$\mathrm{SO}_{\mathbf{4}}$ & $1.17-378.39$ & 253.87 & 72.48 & $500 \mathrm{mg} / \mathrm{L}$ & $100 \mathrm{mg} / \mathrm{L}$ \\
\hline
\end{tabular}

Calcium values ranged from $10 \mathrm{mg} / \mathrm{L}-36 \mathrm{mg} / \mathrm{L}$ with a mean of $26.37 \pm 4.80 \mathrm{mg} / \mathrm{L}$ while potassium values ranged from $0 \mathrm{mg} / \mathrm{L}-6 \mathrm{mg} / \mathrm{L}$ with a mean of $1.38 \pm$ $0.83 \mathrm{mg} / \mathrm{L}$. Calcium deficiency in humans can cause rickets, reduced blood clotting, while elevated calcium levels can lead to cardiovascular diseases (Meride and Ayenew, 2016). The low values recorded for K may be due to the fact that regular sources of $\mathrm{K}$ ions in surface and ground water are absent in piped water (Orewole et al., 2007); there is however, no healthbased drinking were standards for K (Ling et al., 2019; Arega, 2020). Results of anions indicated that bicarbonate was not detected in any of the water samples, while $\mathrm{SO}_{4}$ recorded a range of values between $1.17 \mathrm{mg} / \mathrm{L}$ and $378.39 \mathrm{mg} / \mathrm{L}$ with a mean of $253.87 \pm 72.48 \mathrm{mg} / \mathrm{L}$. However, they were below the WHO limits of $500 \mathrm{mg} / \mathrm{L}$. High sulphate concentrations can cause scale formation and may be associated with a bitter taste in water that can have a laxative effect on humans and young livestock (Orewole et al., 2007). The high occurrence of sulphate is attributed to the Aluminium Sulphate $\left(\mathrm{AlSO}_{4}\right)$ used as a coagulant in water treatment. Very low concentrations were recorded for nitrate, with values ranging from $0.01 \mathrm{mg} / \mathrm{L}-4.23 \mathrm{mg} / \mathrm{L}$ and a mean of $0.23 \pm 0.55 \mathrm{mg} / \mathrm{L}$. Chloride values ranged from $12 \mathrm{mg} / \mathrm{L}-43 \mathrm{mg} / \mathrm{L}$ with a mean of $16.53 \pm 5.90$ $\mathrm{mg} / \mathrm{L}$. Nitrate and Chloride ions recorded values within the acceptable limits of $50 \mathrm{mg} / \mathrm{L}$ and $250 \mathrm{mg} / \mathrm{L}$ respectively (WHO, 2017). The health implication associated with high concentrations of $\mathrm{NO}_{3}$, especially in young children, is the blue baby syndrome, which can cause death in the children (Meride and Ayenew, 2016).
Critical observation of the variation in the values of parameters analysed between the values obtained from the water sample collected at the water treatment plant and the various values obtained at the other sampling points, indicated 6 locations having $\mathrm{pH}$ values lower than that obtained at the treatment plant, which could be attributed to sulphur and amino acid compounds from human and animal excreta (Adekunle et al., 2007). Also, total hardness values were high at four locations; could be attributed to a variety of dissolved polyvalent metallic ions, predominantly calcium and magnesium cations. Three locations had potassium values higher that recorded at the treatment plant; however, $\mathrm{K}$ is important for human body functions like, blood pressure regulation and heart protection (Meride and Ayenew, 2016). Nitrate values for two locations were equally higher than that obtained at the water treatment plant. The major sources of nitrate pollution are domestic waste, industrial waste, sewage, sludge (Eddy and Ekop, 2007; Meride and Ayenew, 2016) which can only get into the distribution network through leaks in the pipes (Casillas et al., 2015). Chloride values higher than that obtained at the treatment plant is attributed to the presence increased electrolytes (Adekunle et al., 2007). The comparison between the result of raw and treated water is presented in Table 2. Seven out of the 13 parameters tested in the treated water were also tested in the raw water result. These include $\mathrm{pH}, \mathrm{EC}, \mathrm{TDS}$, total hardness, calcium, magnesium, and chloride. The average raw water value for $\mathrm{pH}$ was 7.12 , while that of treated water was 6.91. Raw water had an average EC value of $73.88 \mu \mathrm{S} / \mathrm{cm}$ while that of the treated water was $132.10 \mu \mathrm{S} / \mathrm{cm}$. The result of total hardness indicated an average value of $19.93 \mathrm{mg} / \mathrm{L}$ for raw 
water, while that of treated water was $43.39 \mathrm{mg} / \mathrm{L}$. The average raw water value for calcium indicated an average value of $14 \mathrm{mg} / \mathrm{L}$, while that of treated water was $26.37 \mathrm{mg} / \mathrm{L}$. The average raw water value for magnesium was $5.68 \mathrm{mg} / \mathrm{L}$ while that of treated water was $17.3 \mathrm{mg} / \mathrm{L}$. The average raw water value for chloride was $31.25 \mathrm{mg} / \mathrm{L}$ while that of treated water was $16.53 \mathrm{mg} / \mathrm{L}$.

Table 2: Comparison of values of raw and treated water

\begin{tabular}{lllllll}
\hline \multirow{2}{*}{ Parameters } & \multicolumn{2}{c}{ Raw water } & \multicolumn{3}{c}{ Treated water } & \multicolumn{3}{c}{ Standards } \\
\cline { 2 - 7 } & Range & Average & Range & Average & WHO & SON \\
\hline pH & $7.01-7.39$ & 7.12 & $5.63-7.44$ & 6.91 & $6.5-8.5$ & $6.5-8.5$ \\
EC & $25.2-142.9$ & 73.88 & $106-202$ & 132.10 & - & $1000 \mathrm{mg} / \mathrm{L}$ \\
TDS & $10.2-90$ & 32.98 & $53-101$ & 66.07 & - & $500 \mathrm{mg} / \mathrm{L}$ \\
Total alkalinity & - & - & $6-30$ & 8.34 & $100 \mathrm{mg} / \mathrm{L}$ & - \\
Total hardness & $8-42$ & 19.93 & $16-66$ & 43.39 & - & $150 \mathrm{mg} / \mathrm{L}$ \\
$\mathbf{C a}$ & $4-23$ & 14.00 & $10-36$ & 26.37 & $50 \mathrm{mg} / \mathrm{L}$ & - \\
$\mathbf{N a}$ & - & - & $6-40$ & 4.74 & - & $200 \mathrm{mg} / \mathrm{L}$ \\
$\mathbf{M g}$ & $1-19$ & 5.68 & $2-11$ & 17.3 & $0.4 \mathrm{mg} / \mathrm{L}$ & $0.2 \mathrm{mg} / \mathrm{L}$ \\
$\mathbf{K}$ & - & - & $0-6$ & 1.38 & - & - \\
$\mathbf{C l}$ & $18-48$ & 31.25 & $7-43$ & 16.53 & $250 \mathrm{mg} / \mathrm{L}$ & $250 \mathrm{mg} / \mathrm{L}$ \\
$\mathbf{N O}$ & - & - & $0.01-4.23$ & 0.23 & $50 \mathrm{mg} / \mathrm{L}$ & $50 \mathrm{mg} / \mathrm{L}$ \\
$\mathrm{SO}_{\mathbf{4}}$ & - & - & $1.17-378.39$ & 253.87 & $500 \mathrm{mg} / \mathrm{L}$ & $100 \mathrm{mg} / \mathrm{L}$ \\
\hline
\end{tabular}

Except for $\mathrm{pH}$, all the other six parameters (EC, TDS, total hardness, calcium, magnesium, and chloride) had their average raw water values lower than that of the treated water. The average $\mathrm{pH}$ value for the raw water at 7.12, which is almost neutral to alkaline, agrees with the report of Jaji et al. (2007). The fact that the average values for the other six parameters were higher for the treated water than the raw water can be attributed to the addition of water treatment chemicals such as calcium hypochlorite and aluminium chloride in the water treatment process. The result of the statistical analyses indicated that at $p \leq 0.05$, the water samples is adjudged to have met the required Standards Organisation of Nigeria (SON)/WHO standards and is therefore fit for consumption.

Conclusion: The study assessed the quality of the pipe distributed water supplied to Abeokuta city and the effectiveness of the water treatment process. Except for magnesium, all other parameters were within the acceptable limits of the water quality standards used. However, a drop in $\mathrm{pH}$ from the value obtained at the treatment plant while some other parameters experienced increment was observed. It is therefore imperative to note that these variations can only be due to the entrance of foreign matter into the distribution network at some point away from the treatment plant.

\section{REFERENCES}

Adekunle, I., Adetunji, M., Gbadebo, A.M. and Banjoko, O. 2007. Assessment of groundwater quality in a typical rural settlement in Southwest Nigeria. Inter. J. Environ. Res. Pub. Health 4(4): 307-318
Ahmad, M.T. 2017. The role of water vendors in water service delivery in developing countries: a case of Dala local government, Kano, Nigeria. Appl. Wat. Sci. 7(3): 1191-1201

Akoteyon, I.S. 2019. Factors affecting household access to water supply in residential areas in parts of Lagos metropolis, Nigeria. Bull. Geog.. Soc. Econ. Series 43(43): 7-24

Akpor, O.B. and Muchie, M. 2011. Challenges in meeting the MDGs: the Nigerian drinking water supply and distribution sector. J. Environ.l Sci. Technol. 4(5): 480-489

Alam, M., Dafader, N., Sultana, S., Rahman, N. and Taheri, T. 2017. Physico-Chemical Analysis of the Bottled Drinking Water available in the Dhaka City of Bangladesh. Journal of Materials and Environmental Science 8(6): 2076-2083

Arega, T. 2020. Sodium and Potassium Analysis of Drinking Water Quality Assessment and Its Health Effects in Ethiopia: A Retrospective Study. J. Oral Health Dentistry 4(1): 261-266

Balogun, I.I., Sojobi, A.O. and Galkaye, E. 2017. Public water supply in Lagos State, Nigeria: Review of importance and challenges, status and concerns and pragmatic solutions. Cogent Eng. 4(1): 1329776

Balogun, O.R. and Redina, M.M. 2019. Water supply regulation in Nigeria: problems, challenges, solutions and benefits. RUDN J. Ecol. Life Safety 27(1): 65-81 
Boyd, C.E., Tucker, C.S. and Somridhivej, B. 2016. Alkalinity and hardness: critical but elusive concepts in aquaculture. J. World Aquaculture Soc. 47(1): 6-41

Casillas, M.V., Garza-Castañón, L.E., Puig, V. and Vargas-Martinez, A. 2015. Leak signature space: An original representation for robust leak location in water distribution networks. Water 7(3): 1129-1148

Chellan, P. and Sadler, P.J. 2015. The elements of life and medicines. Philosophical Transactions of the Royal Society A: Mathematical, Physical and Engineering Sciences 373(2037): 20140182

Cunha, A.R., Umbelino, B., Correia, M.L. and Neves, M.F. 2012. Magnesium and vascular changes in hypertension. Inter. J. Hypertension 2012

Dirisu, C.G., Mafiana, M.O., Dirisu, G.B. and Amodu, R. 2016. Level of $\mathrm{pH}$ in drinking water of an oil and gas producing community and perceived biological and health implications. European J. Basic Appl. Sci. 3(3):

Eddy, N. and Ekop, A. 2007. Assessment of the quality of water treated and distributed by the Akwa Ibom State water company. J. Chem. 4(2): 180-186

Freije, A.M., Sayeed, S.M. and A, N.H. 2019. Mineral Compositions of Tap, Filtered and Bottled Waters in Bahrain. Inter. J. Recent Tech. Eng. 8(1C2): 571 577

Gröber, U., Schmidt, J. and Kisters, K. 2015. Magnesium in prevention and therapy. Nutrients 7(9): 8199-8226

Hadipuro, W., Wiering, M. and van Naerssen, T. 2013. The sustainability of urban water supply in low income countries: a livelihoods model. J. Water, Sanit. Hygiene for Develop. 3(2): 156-164

Ince, M., Bashir, D., Oni, O., Awe, E., Ogbechie, V., Korve, K., Adeyinka, M., Olufolabo, A., Ofordu, F. and Kehinde, M. 2004. Rapid assessment of drinking-water quality in the federal republic of Nigeria. World Health Organization and UNICEF, Country report of the pilot project implementation in 20052010

Jaji, M., Bamgbose, O., Odukoya, O. and Arowolo, T. 2007. Water quality assessment of Ogun River, south west Nigeria. Environ. Monit. Assess. 133(13): $473-482$
Ling, M.W.J., Anua, S.M. and Mazlan, N. 2019. Concentrations of Magnesium, Calcium and Potassium in Drinking Water; A Comparison between Tap Water and Bore Water. J. Energy and Safety Tech. (JEST) 2(1)

Meride, Y. and Ayenew, B. 2016. Drinking water quality assessment and its effects on residents health in Wondo genet campus, Ethiopia. Environmental Systems Research 5(1): 1-7

Odjegba, E.E., Idowu, O.A., Ikenweiwe, N.B., Martins, O. and Sadeeq, A.Y. 2015. Public perception of potable water supply in Abeokuta south west, Nigeria. J. App. Sci. Environ Manage 19(1): 5-9

Orewole, M., Makinde, O., Adekalu, K. and Shittu, K. 2007. Chemical examination of piped water supply of Ile-Ife in Southwest Nigeria. J. Environ. Health Sci. Eng. 4(1): 51-56

Rahmanian, N., Ali, S.H.B., Homayoonfard, M., Ali, N., Rehan, M., Sadef, Y. and Nizami, A. 2015. Analysis of physiochemical parameters to evaluate the drinking water quality in the state of Perak, Malaysia. J. Chem. 2015

Rusydi, A.F. 2018. Correlation between conductivity and total dissolved solid in various type of water: A review.IOP conference series: earth and environmental science.

Sadiq, A.Y., Oluwasanya, G.O., Eruola, O.A., Ojekunle, O.Z., Odjegba, E.E. and Ahmad, S.M. 2020. Assessment and Mapping of the Spatial Trend in Groundwater Quality in Abeokuta, Nigeria. Nig. J. Sci. Environ. 18 (2):4 - 34

Sutton, S. and Butterworth, J. 2021. Self-Supply Filling the gaps in public water supply provision.Practical Action Publishing Ltd, . Rugby, Warwickshire, UK

WHO 2017. Guidelines for drinking-water quality: Fourth Edition Incorporating the First Addendum.World Health Organization, . Geneva, Switzerland. 631pp

WHO 2019. Progress on household drinking water, sanitation and hygiene 2000-2017: special focus on inequalities.World Health Organization 